\title{
GPT wt Allele
}

National Cancer Institute

\section{Source}

National Cancer Institute. GPT wt Allele. NCI Thesaurus. Code C51023.

Human GPT wild-type allele is located in the vicinity of $8 \mathrm{q} 24.3$ and is approximately $4 \mathrm{~kb}$ in length. This allele, which encodes alanine aminotransferase protein, plays a role in the reversible transamination between alanine and 2-oxog lutarate to generate pyruvate and glutamate. 